УДК 9 : 94 (3) : 930.27

DOI: https://doi.org/10.33782/eminak2021.1(33).490

\title{
DE TITULIS OLBIAE PONTICAE ET VICINIIS. I
}

\author{
Федір Шелов-Коведяєв \\ Незалежний дослідник (Москва, Російська Федерація) \\ e-mail: shel-kov@yandex.ru \\ ORCID: https://orcid.org/0000-0002-6846-2856
}

Стаття присвячена розгляду низки епіграфічних документів, опублікованих різними авторами в останні десятиліття. Не атрибутовані А.І. Іванчиком в IOSPE I3 40 два фрагменти фронтону з написом являють собою початок декрету, який вотований розташованим на півострові Халкідіка полісом Сана на честь громадянина Ніконію. Видані В.П. Алексєєвим і С.Ю. Саприкіним, як ніконійські, три мармурових уламки належать: перший - декрету Ольвії, другий - надгробку боспорянки, третій - херсонеському декрету. Опубліковане тими ж авторами графітто на чорнолаковому черепку є листом Геракліда, який відноситься до часу перебування у Херсонесі трупи акторів. Непрофесійно введена в обіг О.В. Бєлоусовим свинцева пластина, у виправленому вигляді, - ольвійське закляття, відмічене яскравими ознаками навмисного спотворення імен недругів того, хто писав листа.

Ключові слова: епіграфіка, артефакт, фрагмент, поліс, шрифт, лист, декрет, графітто, закляття, надгробок, Ніконій, Ольвія, Херсонес, Боспор

Грецька епіграфіка завжди актуальна. Вона постійно оновлює наші знання про античність. Ї̈̈ особлива цінність полягає у тому, що вона надає дослідникам старожитностей абсолютно аутентичний матеріал. Написи на камені, кераміці, металі й інших носіях дають абсолютно точний відбиток того, що хотіли донести до читача (а у випадку офіційних пам'ятників - і передати через віки) автори текстів. Вони дають безпосереднє уявлення про погляди, вірування, політичні та соціальні інститути давніх еллінів, їх громадське та приватне життя, побут і пристрасті тощо.

Саме тому настільки важливим є адекватне розуміння того, що зберегли для нас відкриті у ході археологічних розкопок документи. Це особливо суттєво, коли мова йде про артефакти, які збереглися до нинішнього часу лише частково.

3 цією метою ця стаття розглядає низку опублікованих раніше фрагментованих об'єктів і, для більш точного розуміння, пропонує виправлення до введених в обіг раніше прочитань.

\section{1. Поліс Сана і Ніконій}

У 2017 p. A.I. Іванчик видав в електронному корпусі IOSPE I3 (Vol. I, nr. 40) знайдені у 1959 р. М.С. Спіциним у ході регулярних розкопок городища Роксолани два уламки мармурової стели, які сходяться по зламу та нині зберігаються в Одеському археологічному музеї НАН України (ОАМ, № 72613). Грунтуючись на аутопсії вересня 2008 р., публікатор дав їм такий опис: Marble, white, with gray (? - Aвm.) veins. H. 6.5, W. 13.6, Th. 2.2. Two joining fragments. The front is carefully planned, other faces are broken off. Find place (мова йде про конкретну топографічну прив'язку - Aвт.): Unknown. Broken off on the right. Probably, just 
one line of text. Margins: left - no less than 6,0; top - no less than 2,0; bottom - no less than 3,2. H. 1.4, W. 5.7. Lettering: Deeply cut but uneven (? - Aвm.) letters, without serifs. Alpha with straight crossbar; $n u$ with a short right vertical, slightly turned outward. Letter heights $(\mathrm{cm})$ : 1.3-1.6. Date: III century B.C.E. Dating criteria: Palaeography. Category: Unknown.

A.I. Іванчик прочитав TANA. За відсутності більш точного археологічного контексту відкриття, доводиться відзначити, що палеографія альфи та ню допускає і більш раннє датування - включно з кінцем V - початком IV ст. до Р.X. (пор. НО 2-4, 56 еtс.).

Для визначення призначення пам'ятника треба придивитися до його зовнішнього вигляду. В оформленні його верхнього (який містить у собі букви) сегменту привертають увагу релікти фронтону. Зокрема, помітні рештки акротерія та полички, що колись вінчали його.

Подібні ознаки (на аналогічно декорованих надгробках епітафії розміщувалися нижче вказаних елементів декору) притаманні офіційним документам. А в них буває, що основному тексту передують або BI адресата(-ів) у давальному відмінку (див. афінський декрет на честь синів Левкона I: IG II² 212 = Syll. ${ }^{3}$ 206; IOSPE I2 340 та інші), або генітив назви общини, яка прийняла рішення (напри-

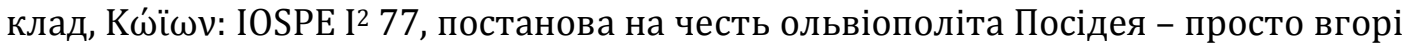
каменю, без фронтону).

Потребує пояснення те, чому від написів нічого до нас не дійшло: адже збережене зліва поле могло помістити в собі уривки початку рядка, а може і двох (маючи на увазі, що розмір літер заголовку - там він дорівнює 13-16 мм - зазвичай більше інших). Причина знаходиться в явно помітних слідах на мармурі, особливо ближче до середини правого уламку, сліди стирання початкового документа.

Крім того, першою уцілілою графемою була не тау, але явна сигма. В неї, готуючись до нанесення нового контенту, намагалися вписати (див. на рис. 1 зкруглення, яке відходить від верхньої горизонталі сигми, та незакінчена округлість, яка йде йому на зустріч від середини) звичайну ро (див. намічене продовження його вертикалі нижче його ж незавершеного напівкола). Для цього сигму навіть почали вибирати: практично зникла нижня горизонталь, вишкрібання очевидне в її верхньому куті. Оскільки різьбяр не досяг успіху у розмежуванні ро (ї̈ петля залишилася від того недописаною) та першої альфи, справа була закинута. Можливо, припиненню роботи «сприяло» і те, що в ході неї камінь розколовся на кілька частин: не можна відкидати, що саме тоді відкололася і його права половина.

Встановлені початкові $\Sigma$ ANA належали або антропоніму, або топоніму. Всі

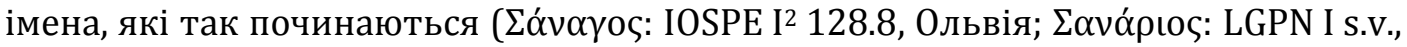
острови Егеїди; $\Sigma \alpha v \alpha \mu \omega \varsigma$ - дається без наголосу - LGPN VB s.v., Карія), відомі тільки у римську епоху та не підходять, оскільки при реконструкції з'являється необхідність уникати анахронізмів.

Тому необхідно зосередитися на топоніміці. Примітно, що одразу два (RE s.v.)

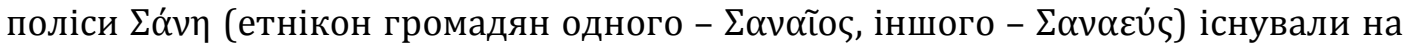
Халкідиці у Північній Греції. А півострів з Подністров'ям ріднить історичний ареал розселення фракійців. Дані обставини дозволяють доповнити gen. plur.

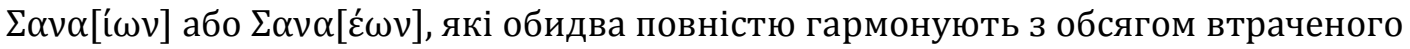
до правого краю стели простором і центруванням фронтону. 
На жаль, нам поки не дано дізнатися, за що саме ті чи інші санайці відмітили ніконійця. Проте, дана сумна обставина ніяк не применшує значення самого факту існування першого для Ніконія раннього іноземного декрету, яким вшанували його громадянина і який розширює наші уявлення про географію зв'язків міста.

\section{2. Епіграфіка Ольвї̈, Херсонеса та Боспору}

У 2004 р. В.П. Алексєєв опублікував ${ }^{1}$, а у 2007 р. С.Ю. Саприкін перевидав ${ }^{2}$ три мармурові фрагменти й одне графітто (рис. 2; 3), які, за твердженням їх власника, були знайдені в Ніконії. 3 опису каменів наводиться лише їх висота - першого (рис. 2.1) 3,5 см, другого (рис. 2.2) 3,7 см, третього (рис. 2.3) 3,9 см та h букв: 0,7$1,1 \mathrm{~cm}^{3}$. Про графітто повідомляється лише «Напис був нанесений <..> на вінчик $<\ldots>$ або на черепок після того, як сосуд був розбитий або пошкоджений», і що по шрифту воно «може відноситися до кінця V - початку IV ст. до н.е.»4.

В.П. Алексєєв жодним чином не ставить під сумнів свідчення, отримані від приватного колекціонера. С.Ю. Саприкін, хоча на початку і робить обмовку в лапідарній частині («Якщо напис дійсно з Ніконія»5), у подальшому виходить 3 ніконійського провенансуб.

На жаль, обидва не врахували загальний ще з радянських часів факт. Городище Роксолани, де локалізується Ніконій, здавна слугувало кар'єром піску і т. ін., а потім піддавалося майже безконтрольному розграбуванню як робітниками, зайнятими на видобутку, так і селянами з околишнього села, яке дало назву археологічному об'єкту. Знахідки ж «щасливців» без особливих перешкод «утікали» на чорні ринки спочатку Білгород-Дніпровського, Тирасполя й Одеси, а звідти - в Київ, Кишинів, Москву, Ленінград і за кордон. Тому «пояснення» «з Ніконія» було найулюбленішою легендою збирачів старожитностей всього СРСР. Достатньо сказати, що коли сприймати слова «антикварів» на віру, то ледве не більшість багатьох типів ольвійських монет з приватних зібрань виявилися б такими, «що походять» з Ніконія.

Наївність, проявлена В.П. Алексєєвим і підхоплена С.Ю. Саприкіним, повела їх хибним шляхом. Крім того, останній чомусь впевнений, що всі три лапідарні уламки відносяться до одного декрета. Його навіть не бентежить те, що суворий силабічний перенос, який він пропонує для всього тексту, порушується саме на збережених уламках ${ }^{7}$, що робить зведену ним конструкцію більше, ніж сумнівною.

Нарешті, дивні, недоречні за формою - у примітках до статті С.Ю. Саприкіна (коли вже зауваження так потрібні, їх варто було б оформити в окрему роботу або додатком до саприкінської публікації) - неповажні спроби С.Р. Тохтасьєва

\footnotetext{
1 Алексеев В.П. Новые материалы к изучению культуры античных городов Северного Причерноморья (Тира - Никоний - Ольвия - Херсонес) // ВДИ. 2004. № 3. С. 68-70. Рис. 61 a-b.

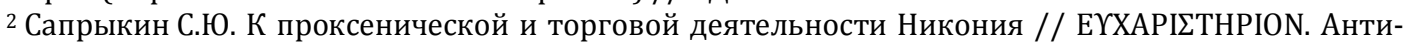
коведческо-историографический сборник памяти Ярослава Витальевича Доманского (19282004). Санкт-Петербург, 2007. С. 63-71.

${ }^{3}$ Алексеев В.П. Указ. раб. С. 68сл.; Сапрыкин С.Ю. Указ. раб. С. 63.

${ }^{4}$ Сапрыкин С.Ю. Указ. раб. С. 68.

5 Ibid. C. 63.

${ }^{6}$ Ibid. C. 64-67.

7 Ibid. C. 64.
} 
додати свої випадкові, розрізнені та приватні «поправки» не внесли потрібної ясності у розуміння епіграфічних уривків. Оскільки, керований одним бажанням «похизуватися» своєю ерудицією, він майже завжди зводить свої addenda et corrigenda або до рутинних і невиправдано дрібних ономастичних зауважень ${ }^{8}$, або до безпідставних міркувань про давньогрецькі діалекти 9 .

Насправді, будучи різночасовими і маючи різні локальні прив'язки форм букв (див. рис. 2), які збереглися на трьох різних каменях, однозначно вказують, що всі вони належать кожного разу іншим написам.

2.1. Декрет з Ольвї (рис. 2.1). Перший напис, який згадує персонажа, котрий надав послуги полісу в критичних для нього обставинах ${ }^{10}$, чиє ім'я чи патрономік починалося на П $\alpha \vartheta \sim$, походить, скоріше за все, з Ольвії. Вона має читатися

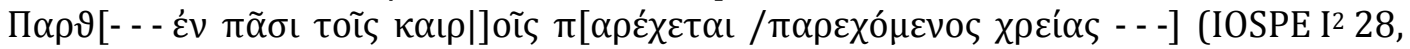

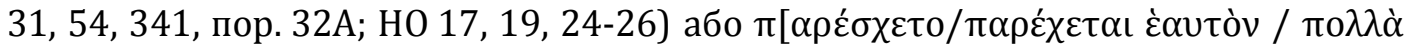
$\left.\delta \varepsilon^{\prime} \gamma \mu \alpha \tau \alpha\right]$ (IOSPE I² 351, 352; НО 42). Хронологічно віддаю перевагу першому варіанту («у важкі часи позичає засоби»), який з’являється в ольвійські епіграфіці набагато раніше другого. У такому випадку, згідно з написанням сигми, наш фрагмент - найбільш давня фіксація цієї формули: до сих пір вона була відома не раніше III ст. до Р.X. (див. НО 17 та ін.). Здається, - і це важко переоцінити відкривається нова сторінка історії стилів декретів Ольвії.

2.2. Боспорський надгробок (рис. 2.2). Другий напис звертає на себе увагою графікою омеги з точкою в середині ї̈ окружності. Таке написання невідоме у містах Північно-Західного Понта. Винятком міг би стати предмет, представлений, як ніконійський, В.П. Алексєєвим у 2001 p. ${ }^{11}$ Але ні за своєю пластикою, ні за геміштом літер з абсолютно різних епох, він не може бути визнаний оригінальним. Проте аналогічне написання омікрона зустрічається у Пантикапеї (див. рис. 412; пор. CIRB Album 109.3). Остання буква рядка 2, всупереч думки С.Ю. Саприкіна, не може бути каппою; їі форма з горизонталлю, яка відходить від середини вертикалі та поєднується далі з вусиками, перебувала б у повній суперечності з іншим шрифтом. Це - ета (пор. її ж у рядку 1), чий вигляд порушений сколами, які понад міру відретушовані на фотографії до першого видання. Так виходить коротка боспорська епітафія заміжньої жінки, чиє ім'я закін-

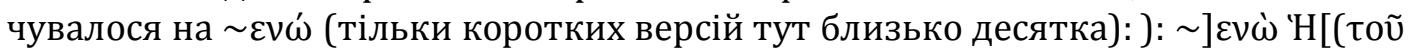

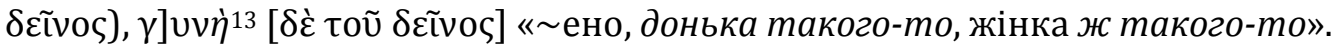

2.3. Херсонеський декрет (рис. 2.3). Третій напис демонструє типовий уривок

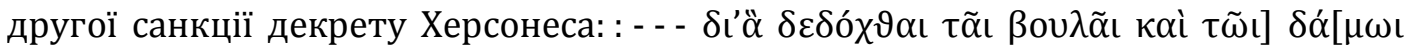

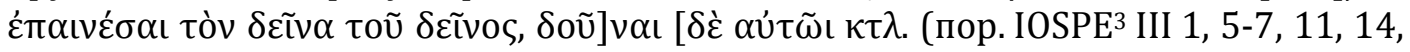
$16,17,19-24,26,31,39,44)$. Подібні формулювання («Рада і Народ на цій підставі постановили прославити такого-то й дарувати йому і т.д.) виникають у

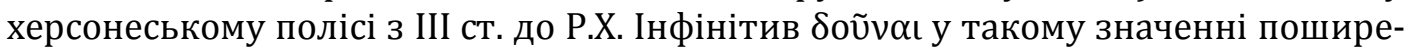

\footnotetext{
8 Ibid. Прим. 7, 8, 11.

9 Ibid. Прим. 10, 18, 19.

10 Про значення лексеми кацроі́ «важкі, небезпечні часи» див., наприклад, Bull. ép. 39, 563; 51, 108

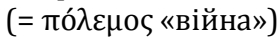

${ }^{11}$ Алексеев В.П. Памятники древних культур из Днестро-Дунайского региона // ВДИ. 2001. № 4. С. 72. Табл. III1

12 Щиро вдячний В.П. Толстікову за надане мені право публікації.

13 Курсивом тут і далі у грецькій відмічені неповністю збережені знаки, в українській - відновлюваний текст.
} 


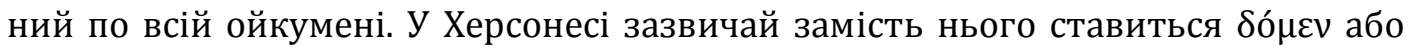

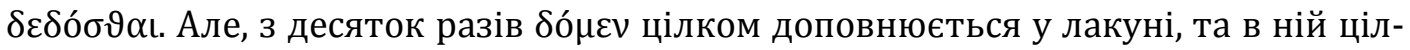

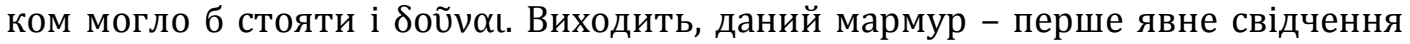
наявності такої форми у Херсонесі.

2.4. Граффіто з Херсонеса (рис. 3). Великий інтерес являє собою останній, датований кінцем V - початком IV ст. до P.X., з артефактів, який привернув у 2007 р. увагу С.Ю. Саприкіна. Він вважав, що «напис на черепку міг бути маршрутом плавання чи шляху суходолом, чи свого роду пам'яткою про межі землі на шляху до Ніконію»14. До цього його підвело читання в рядках 1-2 Т[úpas - - -

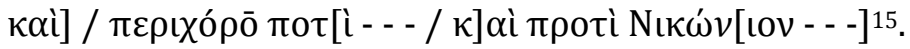

Розглянемо все сказане і пропущене ним по черзі.

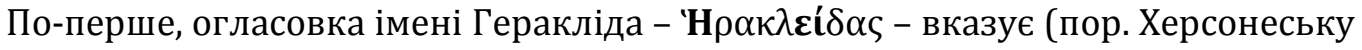
присягу: IOSPE 3 III 100) на епоху койне. У дорійських діалектах на межі V-IV cт.

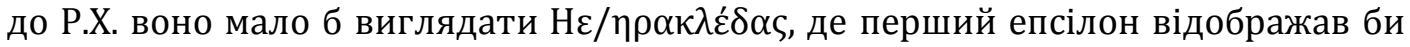
звук [ē], другий рівнявся дифтонгу $\varepsilon$, а H - густому придиху (див. DGEEP 103.8 (Трезена, кінець V ст. до Р.X.), 438.1 (Метапонт, початок IV ст. до Р.X.); пор. 13, 15, 17, 47, 57, 108; 167a2) (Селінунт, колонія Мегари); 321, 350, 362, 363, 419, 439; SGDI 3046, 3048 (Селінунт), cf. 3058 (Візантій)).

По-друге, зауваження С.Р. Тохтасьєва «дане граффіто написано... вже іонійською абеткою» 16 не має значення, оскільки специфічні мегарські, наприклад, графеми вийшли з ужитку задовго навіть до кінця V ст. до Р.X. (верхнього датування С.Ю. Саприкіна).

По-третє, відбивка ВI Геракліда інтерпункцією (крапками) говорить на користь епістолярного жанру запису.

По-четверте, згідно з матеріалом, який зібрав сам перевидавець ${ }^{17}$, поняття «житель навколишніх земель» мало би бути прокреслено у період його нанесення через омегу(

По-п'яте, вже С.Р. Тохтасьєв засумнівався у тому, що один і той же прийменник міг бути виражений єдиним автором у сусідніх рядках по-різному: пот[і́ (рядок 2) і троті́ (рядок 3) ${ }^{19}$.

По-шосте, у передостанній частково уцілілій літері рядка 3 ніщо не вказує бачити омегу, але, напроти, крайня права буква у тому ж рядку, всупереч необгрунтованим сумнівам С.Р. Тохтасьєва ${ }^{20}$, цілком підходить як ню. Нарешті, так само неприпустима ремарка «Четверта буква в рядку 3 зовсім не схожа на ро, на відміну від п'ятої, яка, у свою чергу, не схожа на омікрон»21: навпаки, ро з трикутною петлею прекрасно документована граффіті різних центрів та епох; омікрон же - для порівняння вирізаний у рядку 2 зовсім різними способами, і його трикутна ж форма добре представлена матеріалами граффіті.

Все свідчить про те, що у кінці рядка 3 після прийменника проті́ необхідно реконструювати АН Нікандра або т. п. Виходячи з правильної інтерпретації

\footnotetext{
14 Сапрыкин С.Ю. Указ. раб. С. 69.

15 Ibid. C. 68.

16 Ibid. Прим. 18.

17 Ibid. C. 69.

18 Пор.: Сапрыкин С.Ю. Указ. раб. Прим. 18 (примітка С.Р. Тохтасьєва).

19 Ibid. Прим. 19.

20 Ibid. Прим. 17.

21 Ibid. Прим. 19.
} 
(див. вище) записки, вона являє собою лист Геракліда з дорученням ( ями) деякій особі потурбуватися про забезпечення артистів, які, очевидно, перебувають у Херсонесі і про те/тих, хто/що знаходиться/ яться у/з Нікандра/ ом.

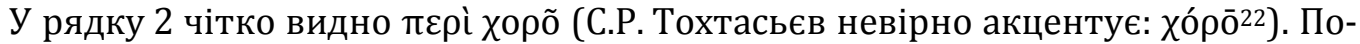

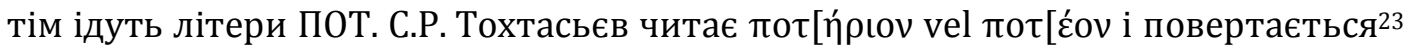
до застільного розуміння напису, який пропонував ще В.П. Алексєєв.

Приймаючи до уваги характер епістоли, тут має розміщуватися або прохання

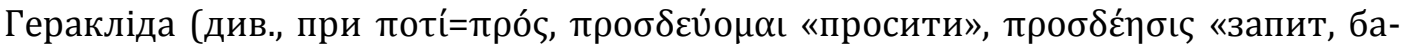

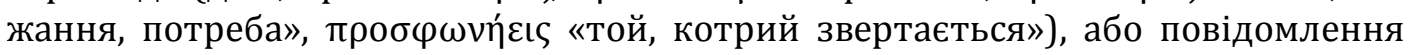

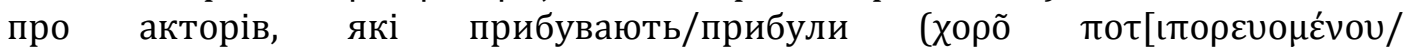

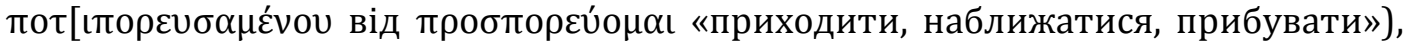

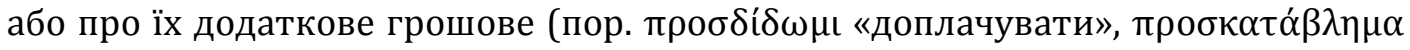
«додаткова плата») чи матеріальне утримання. I хоча, в принципі, не можна відкинути вживання огласовки тот у дієслівній приставці нарівні з прийменником троті́, щоб не множити сутності у фрагментованому тексті, слід звернутися до інших опцій.

Оскільки відомо, що грецькі артисти, крім грошового забезпечення, отримували продукти і вино, ніщо не заважає доповнювати останнє. Звичайно, не

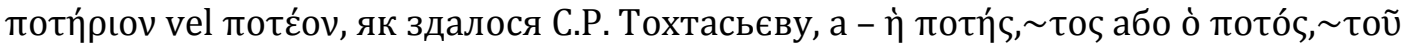
«питво» (LSJ s.v.). Можливо також потаเví «недавно, тільки що».

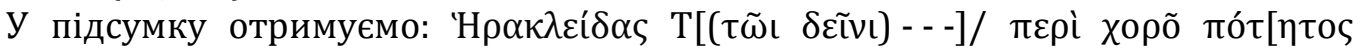

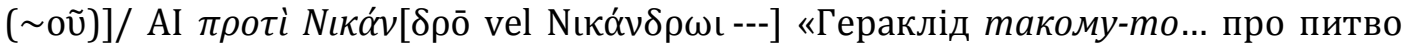
для трупи... у Нікандра / з Нікандром vel sim.». Якщо «з Нікандром» (або схоже ім'я), тоді цей персонаж виявляється керівником групи акторів чи хорегом.

Залишається з'ясувати ситуацію з троті́, похапцем, мимохідь вкрай заплутану С.Р. Тохтасьєвим ${ }^{24}$. Оскільки, так як діалектне джерело прийменника, яке використовував вже у поезії Гомер, не виявлене, ніщо не заважає його появі в апойкії мегарського (по материнському полісу Гераклеї, метрополії Херсонеса) походження. Нічим цьому не заважає матеріал, зібраний у науковій Грецькій Граматиці Едуардом Швіцером 25 . Натомість перша епіграфічна фіксація проті́ у Північному Причорномор'ї робить унікальний внесок в істотне оновлення сучасної бази даних про давньогрецьку мову.

\section{3. Закляття з Ольвії}

У 2017 році О.В. Бєлоусов, наївно довірившись містифікації одного аматора антикваріату, ввів в обіг свинцеву табличку (рис. 5.1 і 5.2), яку він нерозважливо приписав Ніконію26. Неофіта видає не лише те, з яким пафосом, не відаючи реалій південного чорного ринку старожитностей, ним повідомляється, чого йому коштувало домогтися від власника артефакту його провенансу. На додачу він надто улесливо дякує за допомогу зарубіжних колег ${ }^{27}$.

\footnotetext{
22 Ibid. Прим. 18.

23 Ibidem.

24 Ibid. Прим. 19.

25 Schwyzer E. Griechische Grammatik. Bd. I. München, 1977 (Reprint). S. 106; Bd. II. München, 1950

(Reprint). S. 508 u.a.

26 Белоусов А.В. Новое греческое заклятие из Никония // Аристей. 2017. Т. 16. С. 55-64.

27 Ibid. С. 55. Прим. 1.
} 
Підкреслене самоприменшення змушує замислитися про його власний внесок у доволі сумбурний твір. Адже за винятком небагатьох раціональних пасажів, які зобов’язані (якщо вірити публікатору) своєю появою іноземцям, залишаються лише плутаний виклад, який видає незграбного аматора, лавина дивовижних неточностей («на місці некрополя», «джерело історії»: С. 55; висота таблички названа довжиною, вказана вона в 10,5 см при реальному значенні (див. рис.) у 6,5 см, не наведені критерії визначення «внутрішньої» та «зовнішньої» сторін об’єкту: С. 56; в IGDOP 100 двочастинна сигма рядка 1 даремно називається лунарною: тим більше, що там же ще двічі у рядках 1 і 3 вона перетворюється на нечітко виписану звичайну чотиричастинну і т. д.) та претензійна новомова (юпсилон та іота, чотири- та трилінійна сигма замість загальноприйнятих іпсилон, йота і чотири/три/двочастинна і т. п.).

На жаль, нісенітниці катастрофічно множаться з переходом О.В. Бєлоусова до порядкового розбору граффіто, яке містить понад два десятки імен осіб, котрі бажають залишитися безмовними. Тут він виявляє дійсно вражаюче незнання (чи нерозуміння) основ роботи справжнього епіграфіста. А призначивши себе спеціалістом з defixionum tabellae, він повністю легковажить самою суттю уявлень, які водили рукою авторів подібних текстів. I непрофесіоналізм жорстко йому мститься.

Йому невідомо, що неприпустимо - особливо, коли можеш спиратися тільки на фотографію (а аутопсія - одеські колекціонери не люблять пускати до своїх скарбів - недоступна), - щоб кількість знаків в однакових за розміром лакунах сусідніх рядків різнилася у рази. Тому він відновлює на аверсі у рядку 1

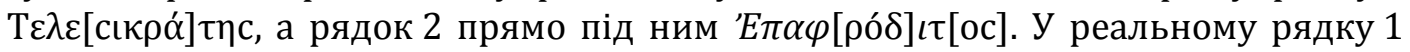
після лямбди помітна лунарна, з легким загином внизу сигма, а за нею - уцілілі рештки йоти; після розриву на свинцю проглядається альфа, далі - видимі ТН $\Sigma$ (сигма двочастинна кутова) та коса риска в кінці. У рядку 2 нема потреби ставити крапки під ЕПАФ: всі літери прекрасно читаються. За лакуною же проглядаються дельта и ITOГ (сигма чотиричастинна). Отримуємо: у рядку 1

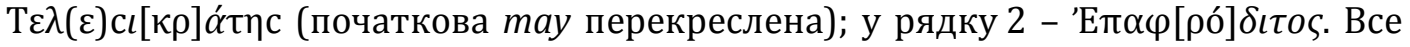
стає на свої місця.

У рядку 3 на четвертій позиції від кінця О.В. Бєлоусов вбачає омегу, процарапану у вигляді кутика вершиною вгору з вусиками, які відходять від середини його сторін. Чимось схоже накреслення омеги підковою з горизонталями, які проходять по її медіані, зустрічається з III ст. до Р.X. в Ольвї̈ (IOSPE I² 32: Протогенівський декрет) і на Боспорі (наприклад, CIRB Album 244), а з II ст. до Р.X. - у Херсонесі (IOSPE I² 466=IOSPE 3 III 298). I гіпотеза видавця могла б мати право на існування. Але, оскільки в усіх інших випадках (рядки 4, 5, 7 аверса і 3, 10 реверса) він сам домальовує у омеги щось схоже на крильця там, де їх на пластині, навіть при багатократному збільшенні у форматі tiff, жодним чином не знайти, i де замість неї постає недописана (без перекладини) альфа, доцільніше прийняти такий же варіант і для рядка 3.

У рядку 5 публікатор даремно на четвертому місці приймає за епсилон свідомо кілька разів перекреслену йоту і не помічає, що після мю на табличці відсутнє місце для закінчення першого антропоніма. Графеми, які залишилися, логі-

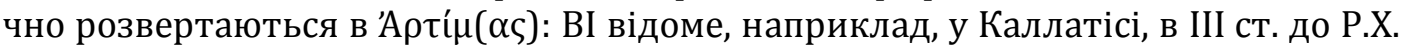
(LGPN IV s.v.). За ним йде (жирним в грецькій далі виділяю спеціально викрив- 
лені автором закляття огласовки та знаки) $\Delta$ เó $\delta \boldsymbol{\alpha} \rho о с$. У рядку $6 \oint i$ багаторазово

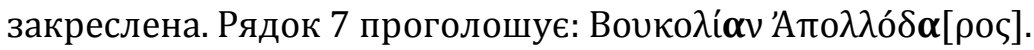

Реверс. У рядках 1-2 О.В. Бєлоусов не вказав, що в кінці АН лакуни вкрали по

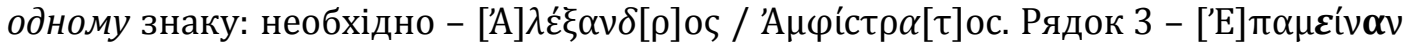
(в збереженому епсилоні середня горизонталь не прописана). Рядок 8:

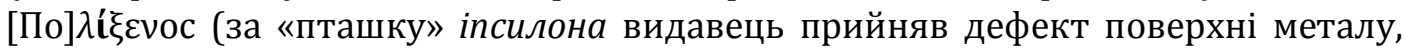

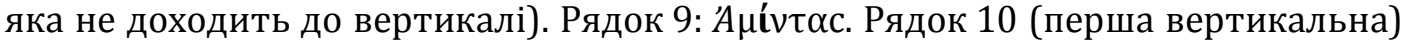

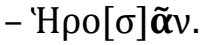

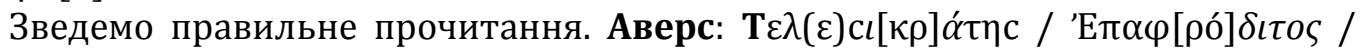

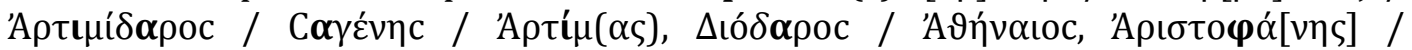

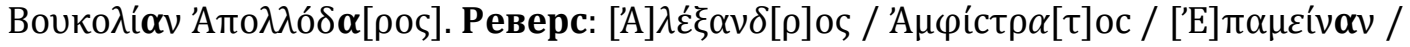

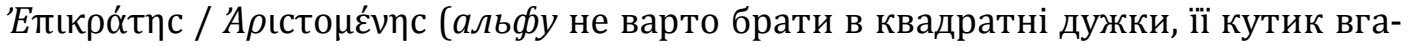

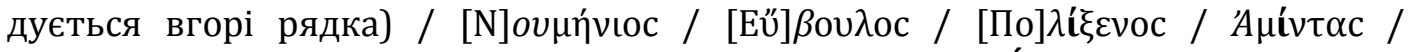

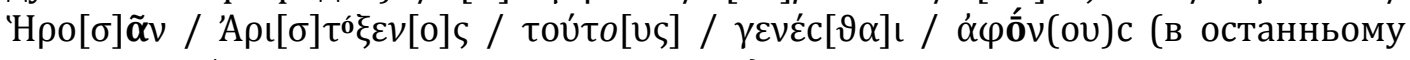
слові потрібні не квадратні, а круглі дужки).

Марною тратою часу і місця постають затягнуті ${ }^{28}$, механічно наслідувані за Мебел Ленг 29 , міркування видавця про «смисл» накреслення сигми то лунарно, то чотиричастинно. Щоб нікого не збивати ними з толку, достатньо послатися на їдку - на адресу таких jeux d'éspris - іронію Луї Роберта та його вказівки (наприклад, ВЕ 74, 369, р. 246-247) на те, що навіть у лапідарних документах змішання різьбярем різних накреслень літер говорить лише про його індивідуальний почерк. I тому (пише Л. Робер) живе письмо не може приносити у жертву сумнівним апріорним принципам, втискуючи розвиток шрифту у мертві застиглі схеми.

Скоромовка О.В. Бєлоусова про ономастичний фонд граффіто 30 - чисте, до того ж неповне та невідрефлексоване, а тому беззмістовне начотництво. Перед нами стандартний набір особистих імен, який не потребує будь-яких коментарів.

Нарешті, зовсім не підходить твердження публікатора - «мова напису яскравих особливостей не несе»31. Зовсім навпаки, іпсилон отримує в ній $y$-подібну форму лише у складі дифтонга ov. В іншому даний звук регулярно замінюється йотою. Не

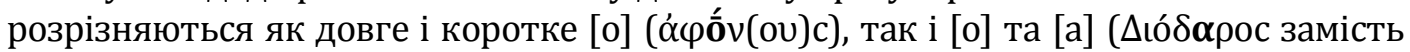

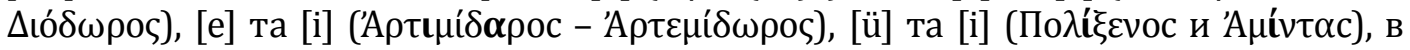

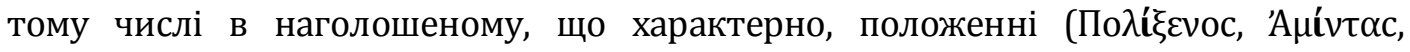

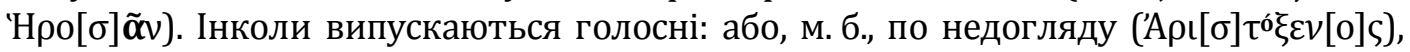

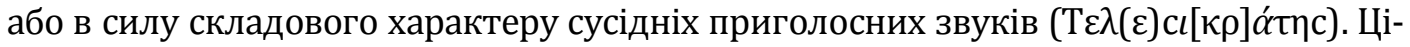

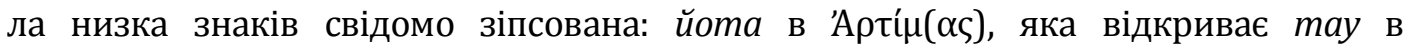

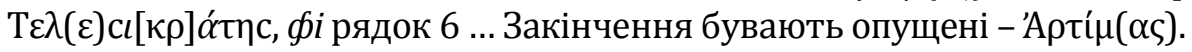

Зовсім непересічне ольвійське, без сумніву, закляття заслуговує більш ретельної уваги. Його видимі «недоладності» можуть бути пояснені двояко. Або в наявності яскравий приклад того, що автор свідомо викривлює імена своїх недругів, щоб завдати їм - у рамках магічних уявлень - максимальної шкоди. Або defixio відкриває для історичної фонетики грецької мови нові риси живого діалекту періоду нанесення запису.

\footnotetext{
28 Ibid. C. 59-61.

${ }^{29}$ Lang M. Writing and Spelling on Ostraka // Studies in Attic Epigraphy, History and Topography presented to Eugene Vanderpool. Hesperia Supplements. 1982. Vol. 19. P. 80-83.

30 Белоусов А.В. Указ. раб. С. 61-62.

31 Ibid. C. 61.
} 
Остання, досить спокуслива, думка мала б пріоритет, коли б справа обмежу-

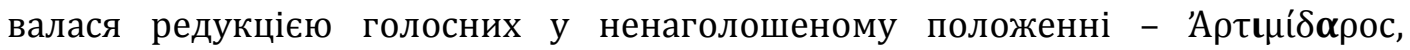

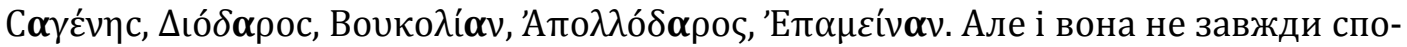
стерігається. 3 іншого боку, - «редукуються» наголошені склади: По $\lambda \dot{\xi} \xi \varepsilon v о c$,

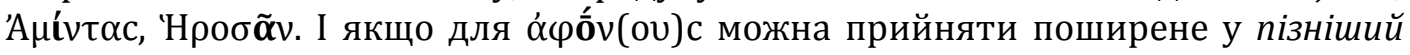
час (викликає сумніви датування пластини IV ст. до P.X., запропонована

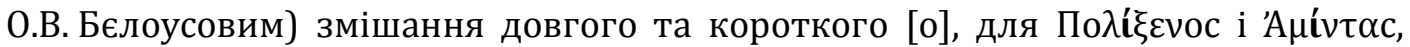
знову ж таки, посилаючись на хронологію процесу, - перехід [ü] в [i], - що по

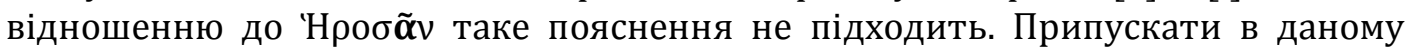
імені щось на зразок властивого римській епосі гіпердорізма теж було б надто сміливо і через ольвійське походження, і через приватний характер напису.

Перераховані міркування, а також те, що сама природа магії вимагає, щоб автор закляття намагався нанести тим, до кого він відчуває недобрі почуття, максимальної шкоди всіма можливими для нього засобами, змушують віддати перевагу першому варіанту. Тим більше, що у чудовій пам'ятці, яка знову підтверджує поширення в Ольвії класичних магічних практик, представлена ще низка ознак, притаманних зверненню з АН ворогів у чаклунських текстах по всій еллінській ойкумені: пропуск / закреслення / недописування букв і складів, вставка нічого граматично не значущих ліній / рисок / значків і т. п.32 Разом $з$ тим, не всі nomina «удостоїлися» бути викривленими: очевидно, таке право «заслужили» тільки ті (втім - таких 2/3) з них, чиї носії найбільше за інших були неприємні автору.

\section{REFERENCES}

Alekseev, V.P. (2001). Pamiatniki drevnikh kul'tur iz Dnestro-Dunaiskogo regiona [Monuments of ancient Cultures from the Area of the Dniestr and the Danube]. Vestnik drevnei istorii, 4, 67-76 [in Russian].

Alekseev, V.P. (2004). Novyie materialy $\mathrm{k}$ izucheniiu kul'tury antichnych gorodov Severnogo Prichernomor'ia (Tira - Nikonii - Ol'viia - Khersones) [New Materials for the Cultural Study of the Ancient North Pontic Cities (Tyras - Niconium - Olbia - Chersonesus)]. Vestnik drevnei istorii, 3, 5879 [in Russian].

Audollent, A. (1904). Defixionum tabellae. Luteciae Parisiorum: A. Fontemoing [in Latin].

Belousov, A.V. (2017). Novoe grecheskoe zakliatie iz Nikoniia [A New Greek Curse from ancient Nikonion]. Aristeas, 16, 55-64 [in Russian].

Collins, D. (2008). Magic in the Ancient Greek World. Oxford: Blackwell Publishing [in English].

Lang, M. (1982). Writing and Spelling on Ostraka / Studies in Attic Epigraphy, History and Topography presented to Eugene Vanderpool. Hesperia Supplements, 19 (pp. 80-83) [in English].

Preisendanz, K. \& Henrichs, A. (1973). Die Griechischen Zauberpapyri. Bd. I. 2. Aufl. Stuttgart: B.G. Teubner [in German].

Preisendanz, K., Heitsch, E. \& Henrichs, A. (1974). Die Griechischen Zauberpapyri. Bd. II. 2. Aufl. Stuttgart: B.G. Teubner [in German].

Saprykin, S.Yu. (2007). K proksenicheskoi i torgovoi deiatel'nosti Nikoniia [For proxenic \& trade Activity of Niconium]. EYXAPILTHPION, 63-71 [in Russian].

Schwyzer, E. (1977). Griechische Grammatik. Bd. I. München: C.H. Beck [in German].

Schwyzer, E. (1950). Griechische Grammatik. Bd. II. München: C.H. Beck [in German].

\footnotetext{
32 Див., наприклад, Audollent A. Defixionum tabellae. Paris, 1904; Preisendanz K., Henrichs A. Die Griechischen Zauberpapyri. Bd. I.2. Aufl. Stuttgart, 1973; Preisendanz K., Heitsch E., Henrichs A. Die Griechischen Zauberpapyri. Bd. II.2. Aufl. Stuttgart, 1974; Collins D. Magic in the Ancient Greek World. Oxford, 2008.
} 


\author{
Fedor Shelov-Kovedyaev \\ (Independent Researcher, Moscow, Russian Federation) \\ e-mail: shel-kov@yandex.ru \\ ORCID: https://orcid.org/0000-0002-6846-2856
}

\title{
De Titulis Olbiae Ponticae et Viciniis. I
}

Greek Epigraphy brings the most important sources for the history of the Hellenic world, and for all the sides of Greek life. Besides the corpus of Greek Inscriptions constantly updates. It is the situation on the North Shore of the Black Sea too. These facts necessitates the periodically re-examination of some epigraphic publications in Russian periodicals.

Regarding that, the paper proposes a number of serious corrections for epigraphical artefacts published in 2004-2017 by A.I. Ivantchik, S.Yu. Saprykin and A.V. Belousov. All of they were presented in the publications as the inscriptions sensational coming from Niconium (lower Dniestr region).

However, we know the archaeological context only for one of them. On the other hand, the «from Niconium» is from Soviet time the loved «explication» of provenance of antiquities marketing on the back markets of Odessa and so one: because of the site of Niconium served as sand quarry for the plants of surrounding industries.

Therefore, only the two marble fragments founded during the regular archaeological excavations on the site of Niconium in 1959 and published by A.I. Ivantchik in 2017 comes really from this Greek city. They are the upper part (the pediment) of the stele conserving the

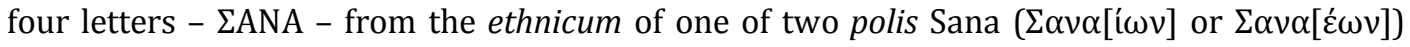
which honored by her decree some Niconian citizen perhaps at boundary of $\mathrm{V}$ and IV centuries B.C.

The one of marble pieces published by S.Yu. Saprykin is the fragment of Olbian decree mentioning the crucial (perhaps a war) circumstances of the city and the person (from his name are preserved only the letters $\Pi \alpha \rho \vartheta)$ who helped his compatriots by money: П $\alpha \rho \vartheta[---$

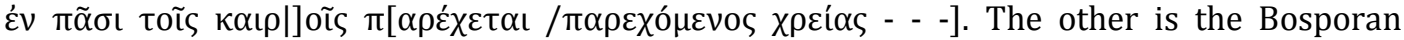

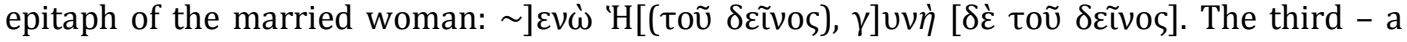
scrap of closing formula of the Chersonesitan decree praising some person: - - $\delta$ ı' $\alpha$ $\delta \varepsilon \delta o ́ \chi \vartheta \alpha \iota$

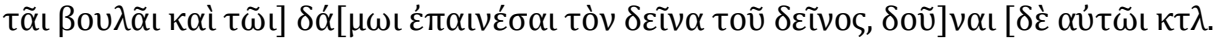

The graffito from the same collection published also by S.Yu. Saprykin tell about the care of an Herakleidas concerning the provision of goods for the theatre company residing in

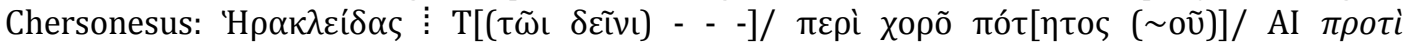

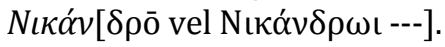

The most rectification of wrongs needed the non-professional publication of Olbian defixio. A.V. Belousov don't master in epigraphical techniques. For this reason he incorrectly reconstruct the lacunae, and don't arrive to understand that the names of the enemies of

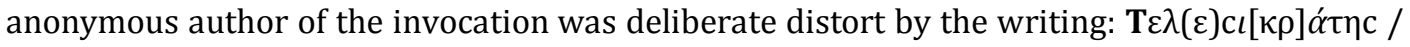

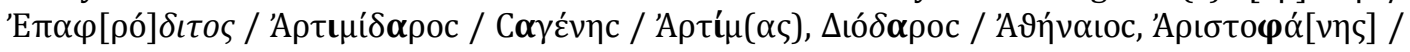

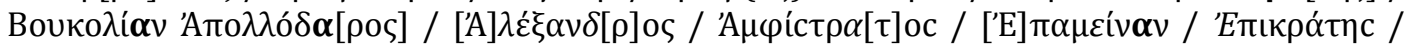

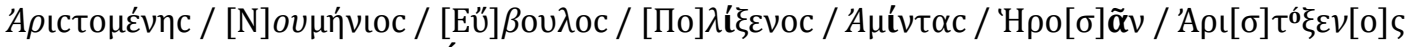

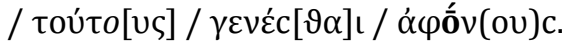

Keywords: epigraphy, artefact, piece, script, decree, letter, polis, graffito, invocation, epitaph, Niconium, Olbia, Chersonesus, Bosporus 


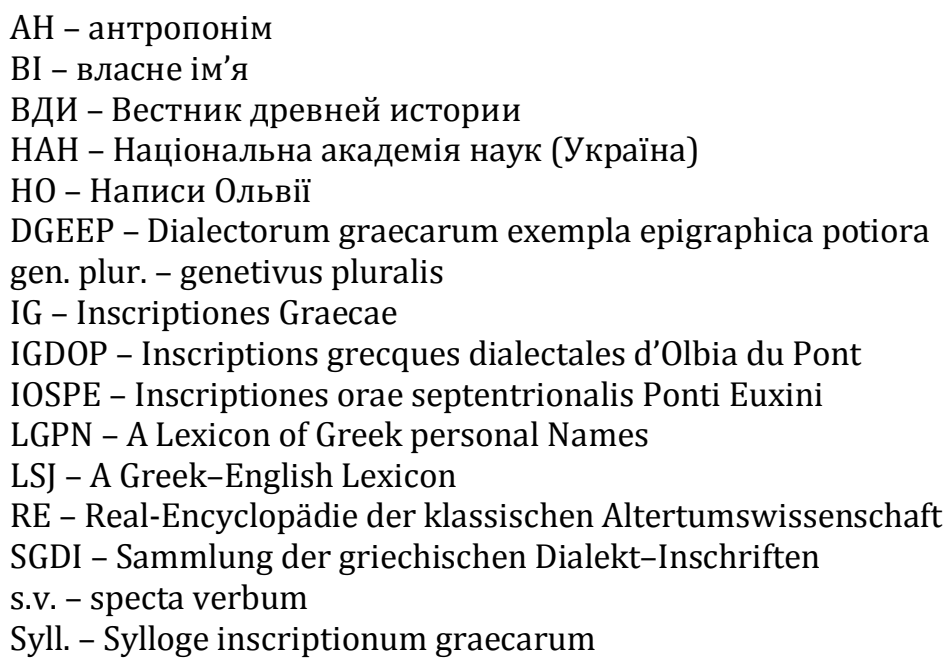




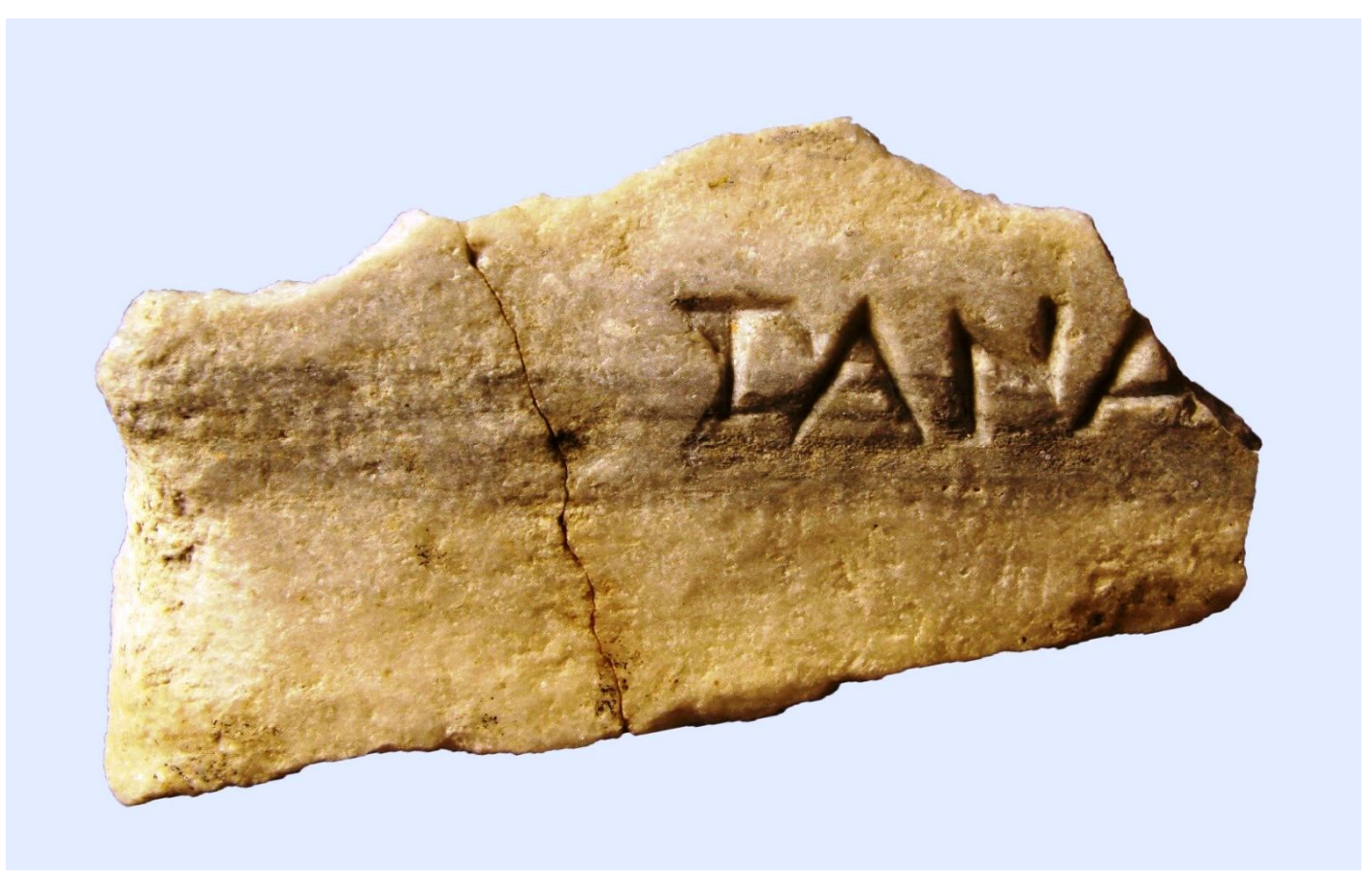

Рис. 1.1.

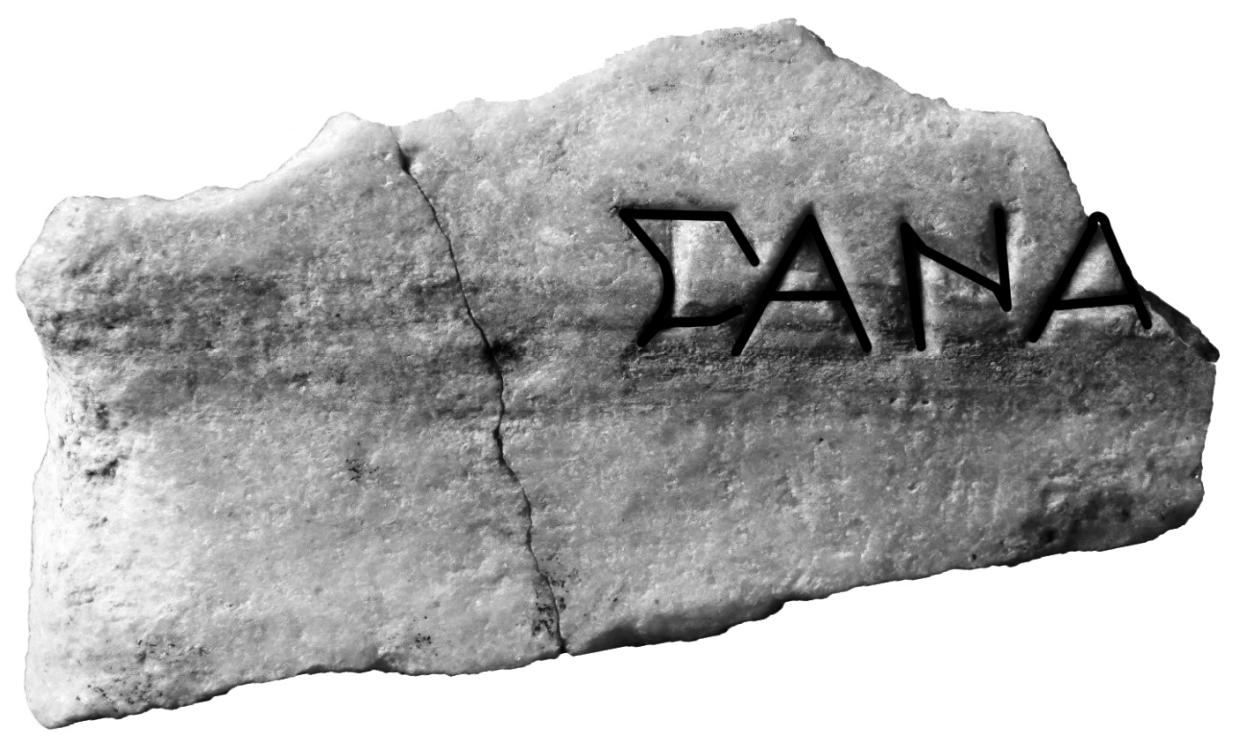

Рис. 1.2.

Рис. 1. Декрет поліса Сани на честь громадянина Ніконія 


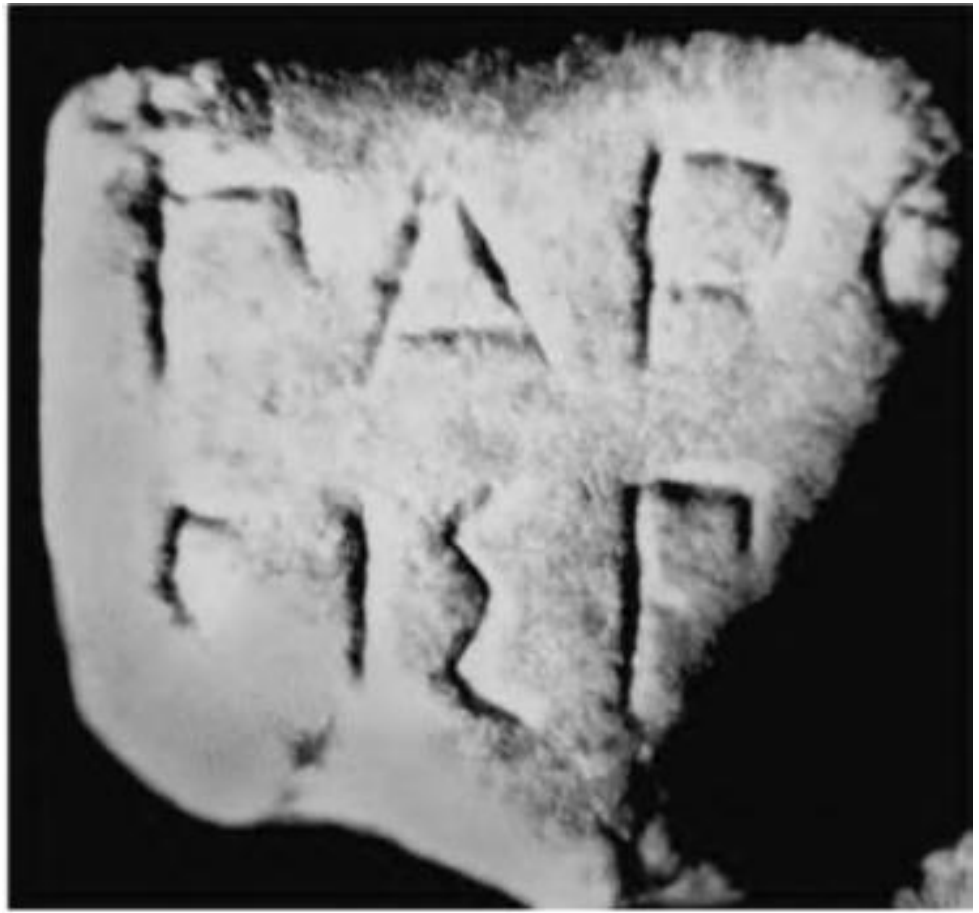

Рис. 2.1. Фрагмент нового ольвійського декрету

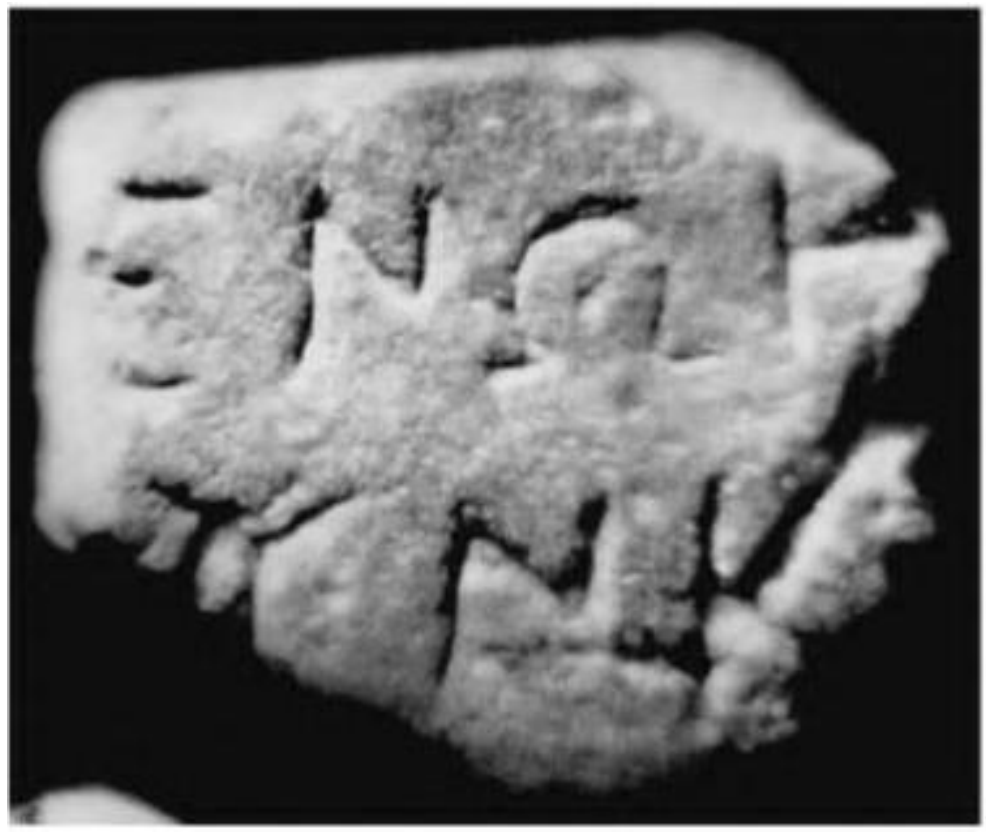

Рис. 2.2. Фрагмент боспорського надгробка 


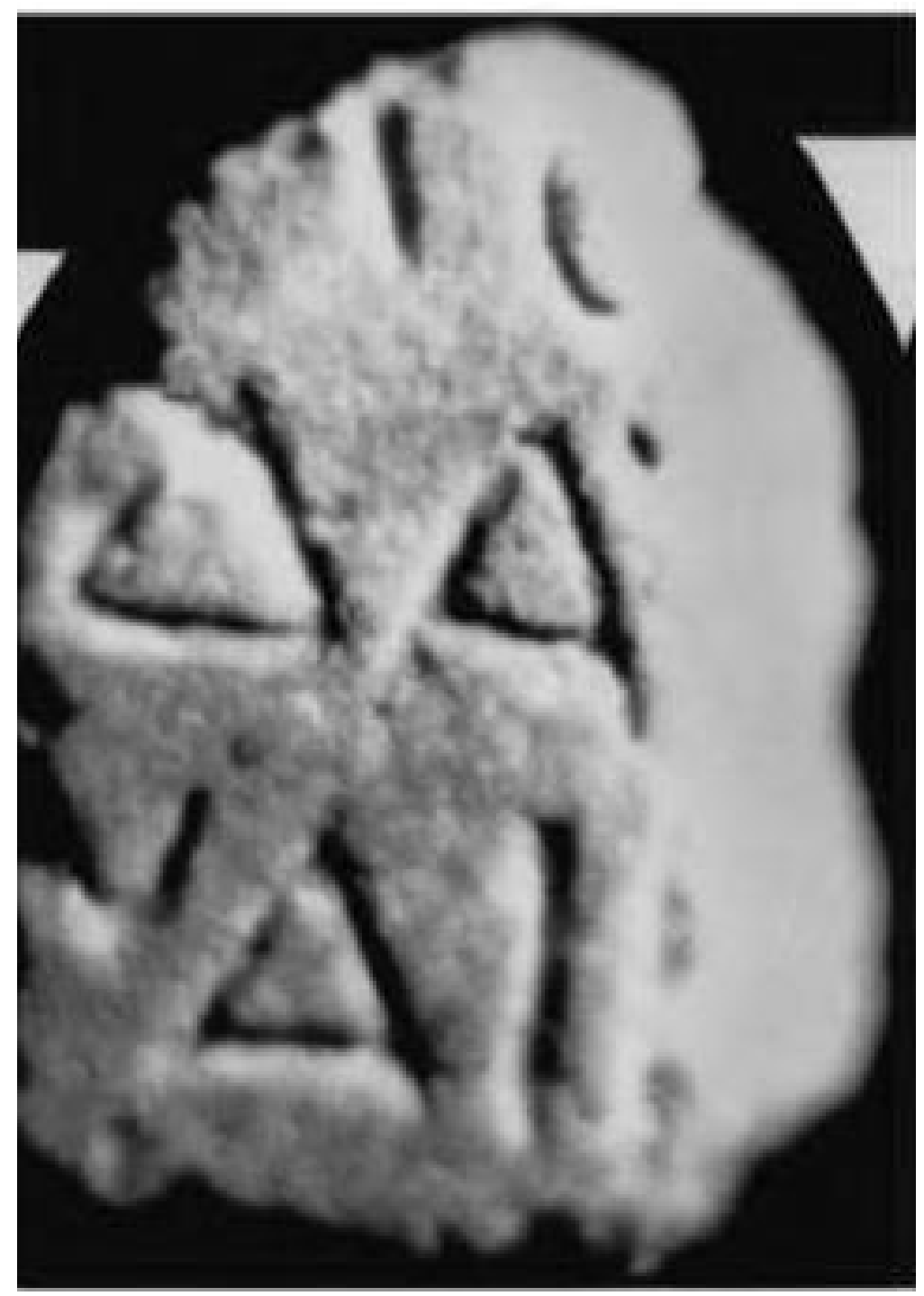

Рис. 2.3. Фрагмент декрету Херсонеса 


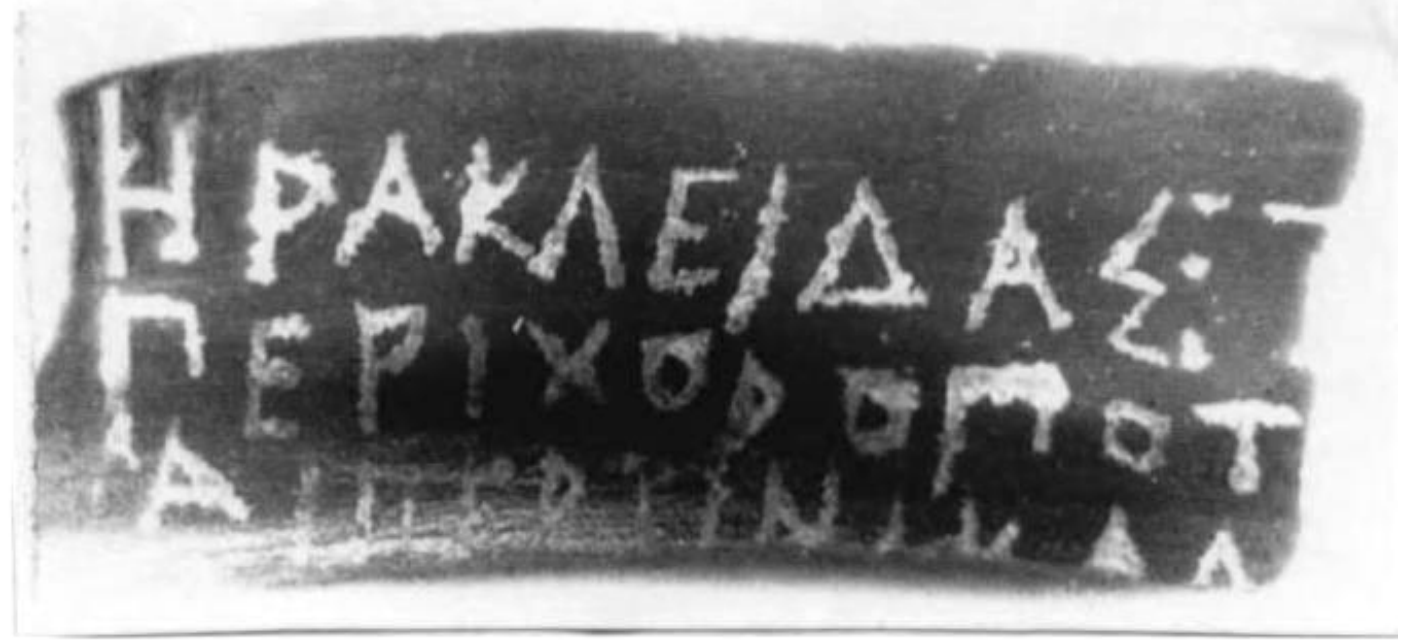

Рис. 3. Лист Геракліда про перебування акторів в Херсонесі

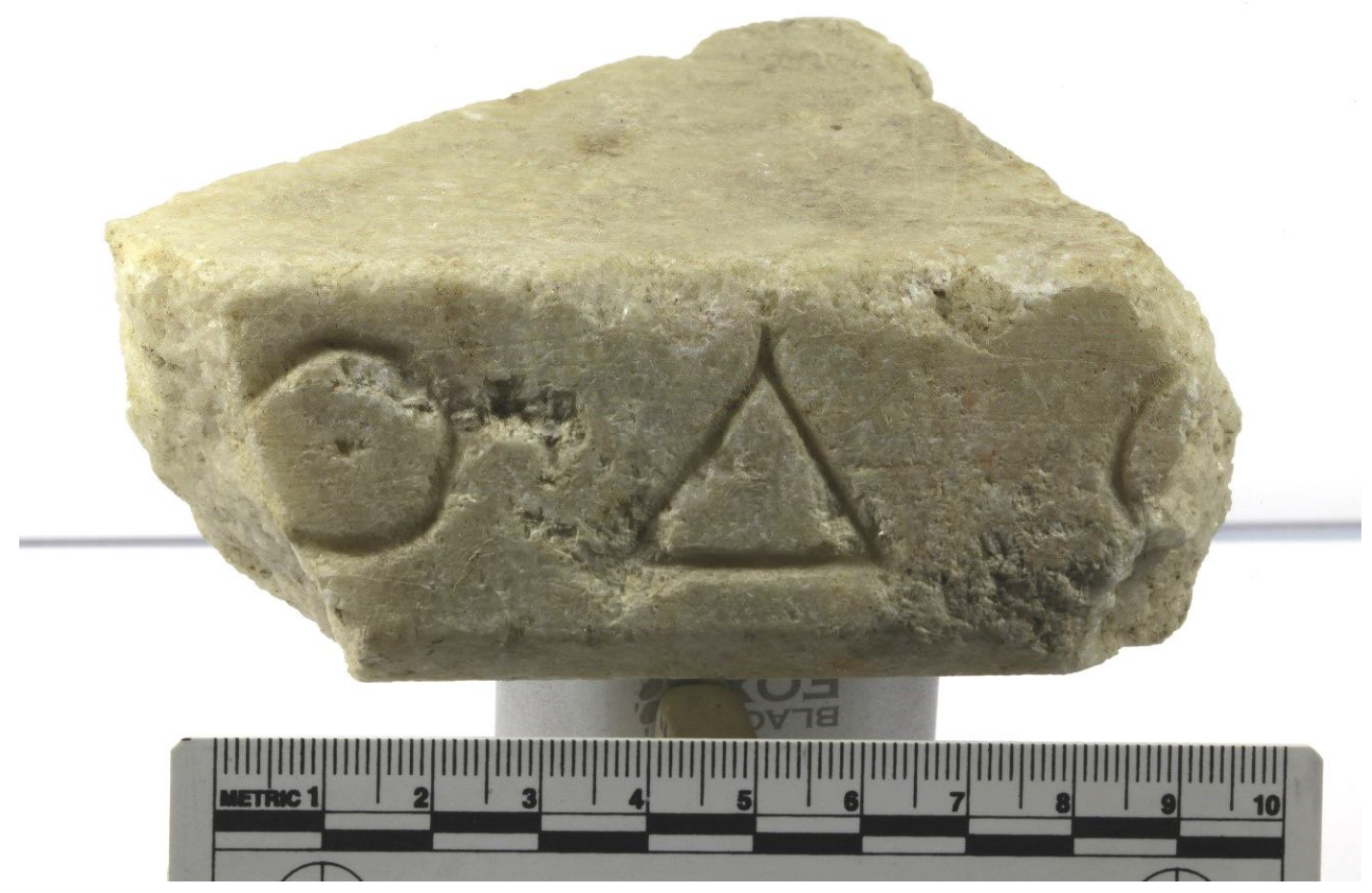

Рис. 4. Фрагмент пантікапейського напису 


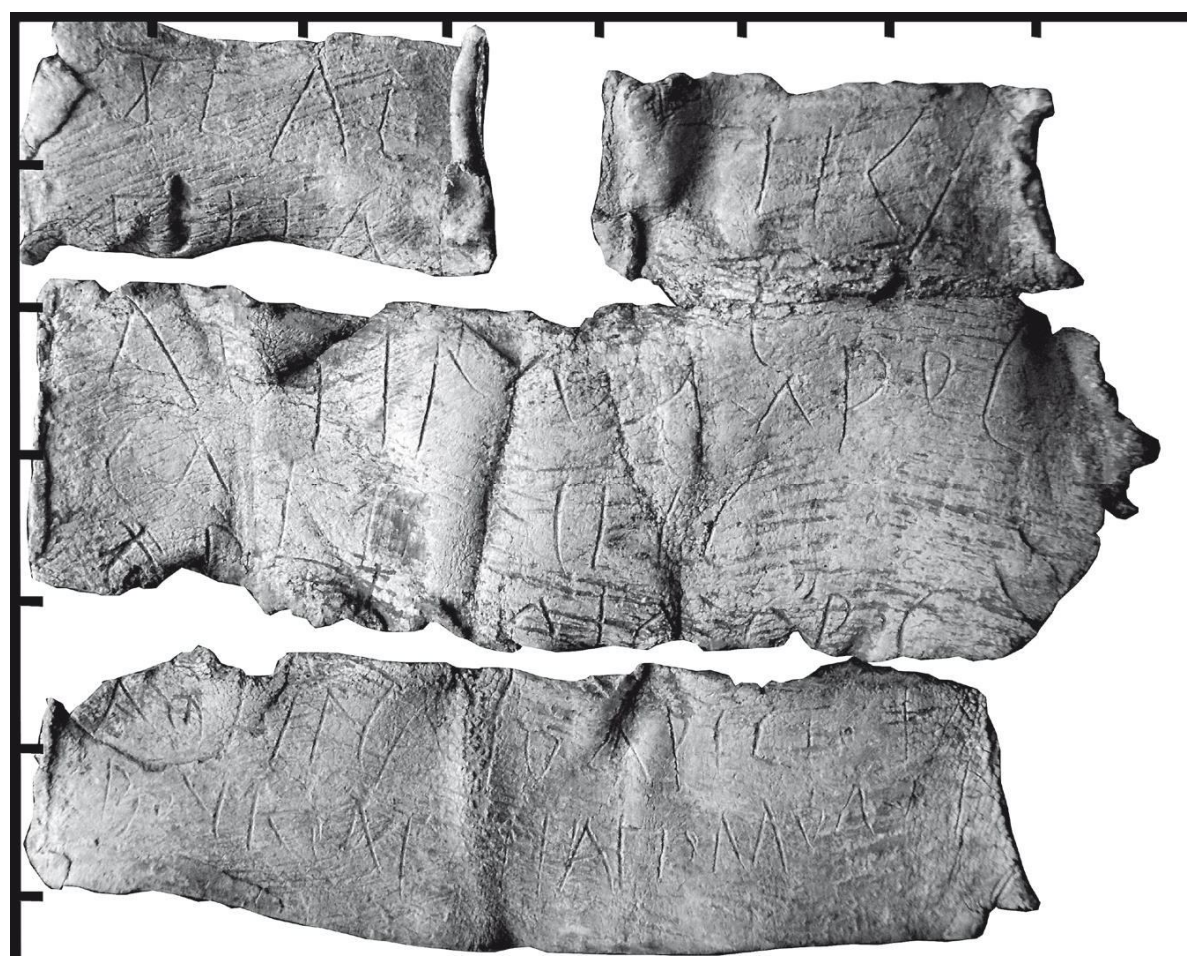

Рис. 5.1. Ольвійське закляття. Аверс

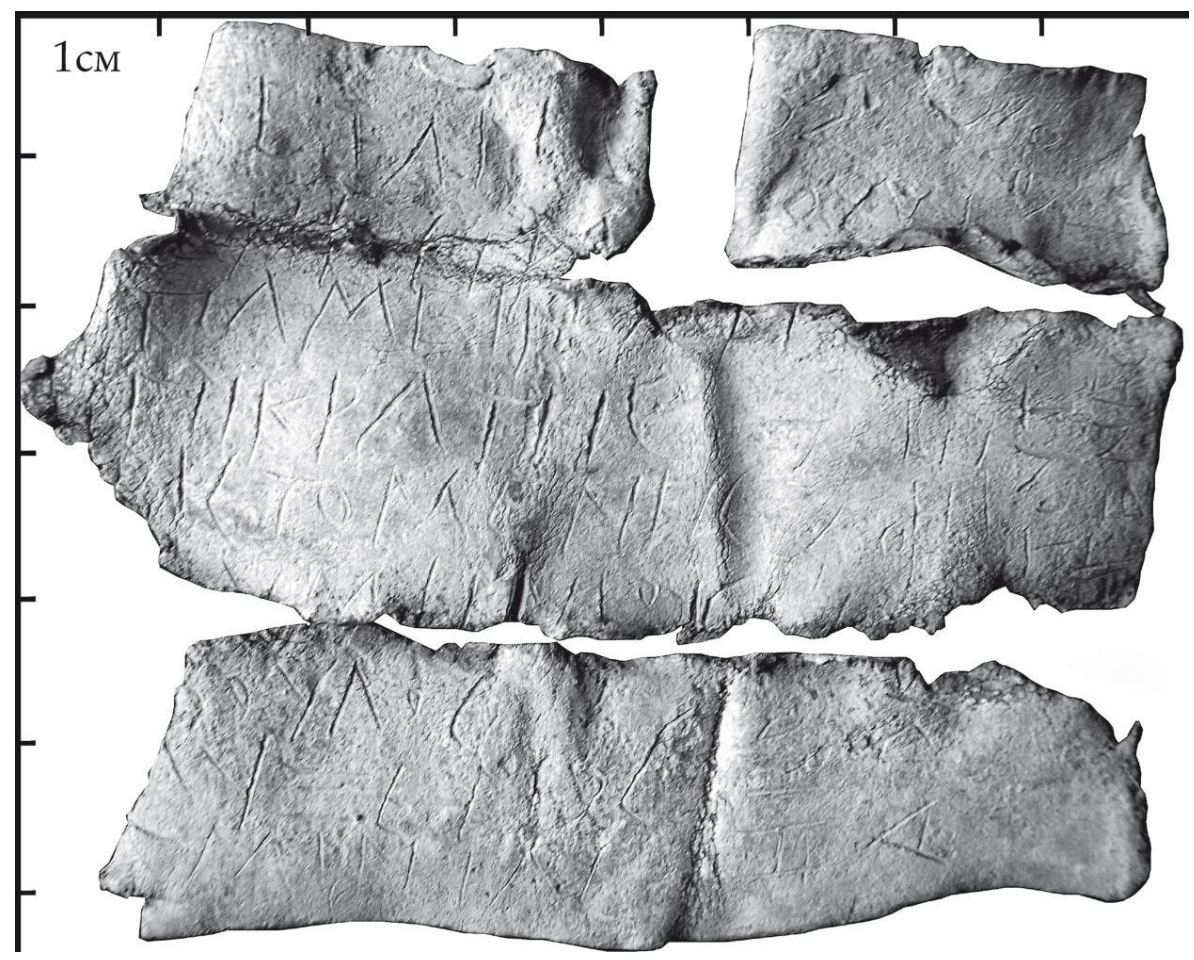

Рис. 5.2. Ольвійське закляття. Реверс 